\title{
Nuansa
}

\author{
Jurnal Penelitian IImu Sosial dan Kegamaan Islam
}

Vol. 17 No. 2 Juli - Desember 2020

\section{Pola Penerimaan Peserta Didik Baru Berbasis Zonasi di SMPN dan SMAN Pamekasan}

\author{
Saiful Arif \\ Fakultas Tarbiyah Institut Agama Islam Negeri Madura \\ saifularif7691@gmail.com
}

\begin{abstract}
Abstrak:
Kebijakan baru pemerintah dalam dunia pendidikan dengan menggunakan pola zonasi pada penerimaan peserta didik baru di sekolah, menimbulkan banyak reaksi dan penolakan dari masyarakat, bahkan pada tahun ajaran baru 2019/2020, ketika kebijakan ini dilaksanakan, banyak gejolak yang hampir secara nasional terdapat unjuk rasa terhadap pola ini. Artikel ini berusaha menyajikan persoalan di sekitar pelaksanaan zonasi yang menjadi kebijakan pemerintah secara nasional, dengan mengambil potret di Pamekasan. Penelitian ini bertujuan untuk mengidentifikasi tentang respon masyarakat, respon sekolah, dan optimalisasi pemerataan pendidikan pola zonasi pada peneriman peserta didik baru pada sekolah di Pamekasan. Penelitian ini menggunakan pendekatan kualitatif diskriptif dengan sumber data kepala sekolah, guru, peserta didik, orang tua, dan masyarakat. Pengumpulan data menggunakan wawancara mendalam, observasi langsung, dan analisis dokumentasi. Hasil penelitian yang diperoleh adalah sebagian besar respon masyarakat dan sekolah di Pamekasan tidak setuju dengan pola zonasi, diantara alasan yang diberikan adalah menutup peluang anak yang memiliki prestasi tinggi yang berada di luar zona tidak bisa masuk di sekolah yang dipandang favorit yang ada di jantung kota, serta ternyata pola zonasi belum sepenuhnya optimal memeratakan pendidikan kepada semua sekolah.
\end{abstract}

(The government's new policy in the world of education by appying school zoning policy in the admission of new students in schools causes a lot of reactions and resistance from the community, esspecially, in the new academic year 2019/2020. This policy raises many turmoils such as demonstrations against it. This article attempts to present the issues surrounding the implementation of school zoning as a national government policy, by focusing its' implementation in Pamekasan. This study aims to identify community responses, school responses, and optimization of the distribution of zoning pattern education in the admission of new students to schools in Pamekasan. This study used a descriptive qualitative approach with data sources for principals, teachers, students, parents, and the community. Collecting data used are in-depth interviews, direct observation, and documentation analysis. The results of the research obtained that most of the community and school responses in Pamekasan do not agree with the school zoning, among the reasons given is closing the opportunities for children with high achievement living outside the zone cannot enter the favorites schools locating in the center of the city. Moreover, the school zoning has not been optimally distributing the quality of education to all schools).

Kata Kunci:

Penerimaan; Peserta Didik; Zonasi 


\section{Pendahuluan}

Pendidikan menjadi hak bagi setiap warga negara Indonesia, hal ini sesuai dengan tuntutan UUD 1945 pasal 31, menyatakan "setiap warga negara memiliki hak untuk mendapatkan pendidikan dan pengajaran, tentunya berimplikasi kepada pemerintah untuk menyelenggarakan pendidikan dengan sebaik-baiknya sebagai perwujudan adanya kewajiban untuk memenuhi tuntutan hak yang dimiliki oleh setiap warga negara. Dalam Undang-Undang nomor 20 tahun 2003 tentang Sistem Pendidikan Nasional pasal 1 ayat (1) dinyatakan bahwa pendidikan adalah usaha sadar dan terencana untuk mewujudkan suasana belajar dan proses pembelajaran agar peserta didik aktif mengembangkan potensi dirinya untuk memiliki kekuatan spiritual keagamaan, pengendalian diri, kepribadian, kecerdasan, akhlaq mulia, serta keterampilan yang diperlukan dirinya, masyarakat, bangsa dan negara. Karena itu, pembangunan pendidikan merupakan prioritas utama dalam agenda pembangunan nasional".

Pendidikan menjadi strategis untuk dilakukan dengan sungguh-sungguh dan dikelola secara profesional. Ini menjadi keniscayaan karena perannya yang sangat signifikan dalam mencapai kemajuan kehidupan masyarakat di berbagai segmen kebutuhan. "Pemerintah berkewajiban memenuhi hak setiap warga negara dalam memperoleh layanan pendidikan guna meningkatkan kualitas hidup bangsa sebagaimana diamanatkan oleh UU nomor 20 tahun 2003 tentang Sistem Pendidikan Nasional pada pasal 3 ditegaskan bahwa pendidikan nasional berfungsi mengembangkan kemampuan dan membentuk watak serta peradaban bangsa yang bermartabat dalam rangka mencerdaskan kehidupan bangsa, bertujuan untuk berkembangnya potensi peserta didik agar menjadi manusia yang beriman dan bertaqwa kepada Tuhan Yang Maha Esa, berakhlaq mulia, sehat, berilmu, cakap, kreatif, mandiri, dan menjadi warga negara yang demokratis dan bertanggung jawab. Pendidikan sebagai hak setiap warga negara dalam realitasnya masih banyak persoalan yang dihadapi, diantaranya adalah kurang meratanya pendidikan di Indonesia menjadi suatu masalah klasik yang hingga kini masih menyisakan langkah strategis dari pemerintan untuk menanganinya".

Beberapa masalah pendidikan yang masih aktual dan menarik untuk diperbincangkan dewasa ini antara lain : "(1) sebagian besar pendirian lembaga pendidikan prasekolah yang diprakarsai oleh masyarakat masih berorientasi di wilayah perkotaan, sedangkan untuk wilayah-wilayah di pedesaan atau daerah terpencil dirasakan masih sangat kurang. Hal ini berakibat pada kurangnya pemerataan kesempatan untuk pendidikan prasekolah, ${ }^{2}$ (2) masih terdapat pendirian/penyelenggaraan pendidikan prasekolah tidak memenuhi standar minimal baik dari segi sarana dan prasarana maupun mutu dan profesionalisme guru, ${ }^{3}$ (3) kondisi sosial ekonomi masyarakat di pedesaan dan daerah terpencil yang sebagian besar miskin telah menyebabkan kualitas gizi anak kurang dapat mendukung aktivitas peserta didik dalam bermain sambil belajar, (4) banyak penyelenggaraan pendidikan prasekolah terutama di kota besar, kurang memperhatikan kurikulum dengan mempraktekkan pola pendekatan terhadap anak didik terlalu berorientasi akademik dan memperlakukannya sebagai orang dewasa kecil yang dapat menyebabkan terjadinya proses pematangan emosi anak menjadi kurang seimbang, (5) munculnya deskriminasi pendidikan yang diberikan oleh masyarakat dengan predikat sekolah favorit dan tidak favorit, serta (6) pemerataan kesempatan mendapatkan layanan pendidikan

\footnotetext{
${ }^{1}$ Mulyasa, Manajemen Berbasis Sekolab (Konsep, Strategi, dan Implementasinya), (Bandung: Remaja Rosdakarya, 2003$), 57$

2 Tilaar, Manajemen Pendidikan Nasional, (Bandung: Remaja Rosdakarya, 2006), 133

3 Aniek Indrawati, "Pengaruh Kualitas Layanan Lembaga Pendidikan terhadap Kepuasan Konsumen", Jurnal Ekonomi Bisnis, Th. 16 No. 1, (Maret, 2011), 36
} 
berkualitas terutama bagi warga negara yang ada di daerah terpencil, terdepan, dan terbelakang (3T)". ${ }^{4}$

Diantara upaya membuka akses memperoleh kesempatan pendidikan yang merata adalah "kebijakan terbaru yang dilakukan pemerintah dalam pemerataan pendidikan di sekolah dengan menggunakan pola zonasi pada penerimaan peserta didik baru. Kebijakan ini tetuang dalam Permendikbud nomor 14 tahun 2018 tentang Mekanisme Penerimaan Peserta Didik Baru sebagai pengganti Permendikbud nomor 17 tahun 2017. Permendikbud ini mengatur mekanisme penerimaan peserta didik baru dengan pola zonasi. Pola zonasi dimaksudkan; (1) untuk pemerataan akses pendidikan seluruh peserta didik secara adil, tanpa diskriminasi, sehingga peserta didik yang berbakat, baik secara kognitif, afektif, maupun psikomotorik tersebarkan pada lembaga sekolah secara merata, (2) yang menjadi dasar peserta didik diterima adalah jarak peserta didik dengan sekolah, (3) semua sekolah harus memiliki level yang sama, terutama dalam kualitas, untuk itu, sekolah harus berusaha meningkatkan kualitas, termasuk sekolah yang dianggap tidak favorit. Label sekolah favorit dan tidak favorit mau dihilangkan. Peserta didik yang pintar tidak menumpuk pada satu sekolah yang berlabel favorit, tidak mau masuk ke sekolah yang tidak favorit. Permendikbud ini hanya diberlakukan di sekolah di bawah Kementerian Pendidikan dan Kebudayaan yang berstatus Negeri".

Implementasi Permendikbud dimaksud, khususnya realitas yang terjadi di Pamekasan, "ketika penerimaan peserta didik baru tahun pelajaran 2018/2019, semua sekolah negeri belum memenuhi jumlah pendaftar sesuai dengan pagu yang ditetapkan. Untuk SMAN hanya SMAN 1 dan SMAN 3 yang memenuhi dari kuota yang ditetapkan, sedangkan yang lain jumlah pendaftar di bawah pagu yang ditetapkan. Padahal sebelum kebijakan zonasi ini diberlakukan, hampir semua sekolah yang ada di perkotaan jumlah pendaftar melampaui pagu yang ditetapkan. Ada fenomena yang menarik dijumpai terutama di kalangan masyarakat perkotaan dari ekonomi menengah ke atas untuk memondokkan anaknya ke pondok pesantren yang memiliki lembaga formal yang berkualitas sebab kebijakan zonasi yang kebetulan zonanya masuk pada sekolah yang menurut masyarakat dipandang tidak favorit". ${ }^{5}$ Dari paparan di atas, maka dapat ditegaskan fokus penelitian ini adalah respon masyarakat, respon sekolah, dan optimalisasi pemerataan pendidikan berbasis zonasi.

\section{Metode Penelitian}

Pendekatan penelitian yang digunakan adalah kualitatif (qualitative approach) dengan metode deskriptif. Peneliti berusaha mengidentifikasi realitas yang sebenarnya terjadi dengan mendengarkan, mengamati, dan menganalisis dokumentasi yang ada dan kemudian mengolah dan menganalisis data itu sesuai dengan fokus yang peneliti lakukan tanpa ada intervensi terhadap kenyataan yang terjadi.

Dalam penelitian ini, peneliti melakukan koordinasi dengan Kepala Kantor Cabang Dinas Pendidikan Jawa Timur di Pamekasan, Kepala kantor Dinas Pendidikan Kabupaten Pamekasan, kemudian beberapa kepala sekolah, beberapa guru, beberapa peserta didik dan beberapa orang tuanya di SMPN dan SMAN, serta beberapa anggota masyarakat yang ada di kecamatan kota Pamekasan guna memperoleh informasi. Kemudian pengumpulan data disesuaikan dengan waktu senggang peneliti.

\footnotetext{
${ }^{4}$ Sabar Budi Raharjo, "Evaluasi Trend Kualitas Pendidikan Di Indonesia", Jurnal Penelitian Dan Evaluasi Pendidikan, Tahun 16 Nomor 2, (2012), 517

${ }^{5}$ Mochammad Tarsun Kadisdik Kabupaten Pamekasan, wawancara, (1 April 2019)
} 
Data yang diperoleh peneliti, kemudian dianalisis melalui reduksi data, penyajian data, pengambilan kesimpulan dan verifikasi. Tahapan ini berlangsung secara interactive analysis, dengan model interaksi siklus, yang dilakukan selama dan sekaligus setelah pengumpulan data.

\section{Hasil dan Pembahasan \\ Respon Masyarakat}

Respon sebenarnya berorientasi pada sikap dan pandangan. Respon masyarakat Pamekasan adalah sikap dan pandangan mereka terhadap pola penerimaan peserta didik baru berbasis zonasi. Sikap dan pandangan mereka cukup beragam. Sangat banyak masyarakat yang tidak setuju dengan kebijakan zonasi ini. Tapi ada juga beberapa masyarakat yang setuju. Mereka yang tidak setuju berpandangan bahwa penerimaan peserta didik baru pola zonasi tidak memberikan keleluasaan untuk memilihkan sekolah bagi anaknya. Seperti yang dikatakan oleh salah satu informan, bahwa zonasi sebenarnya membatasi keinginan masyarakat memilih sekolah untuk anaknya, masyarakat diberi keterbatasan memilih sekolah. Padahal masyarakat menginginkan anaknya dapat melanjutkan ke lembaga pendidikan yang dianggap unggul. ${ }^{6}$

Zonasi yang dijadikan kebijakan baru oleh pemerintah, kurang memahami kemauan masyarakat. Kemauan masyarakat pasti menginginkan anaknya dapat mengikuti pendidikan di sekolah yang dianggap favorit oleh masyarakat. Tetapi dengan adanya kebijakan zonasi ini, ketika anak mereka ternyata di luar zonasi sekolah yang dipandang favorit, maka pupuslah harapan mereka, padahal mereka sudah memiliki keyakinan yang kuat, ketika anak mereka mengenyam pendidikan di sekolah yang dipandang favorit, pasti ketika melanjutkan pada jenjang yang lebih tinggi kemungkinan besar, bisa juga diterima di sekolah yang dianggap favorit oleh masyarakat. Masyarakat sudah memiliki kepercayaan yang tinggi pada sekolah yang dipandang favorit, sehingga dapat memberikan harapan besar pada masa depan anaknya.

Respon masyarakat Pamekasan yang menyikapi kurang baik terhadap pola zonasi, mereka berpandangan, kebijakan zonasi ini, mengabaikan kompetisi secara akademik, lebih menekankan hanya pada jarak rumah dengan sekolah, mengabaikan prestasi yang dimiliki oleh calon peserta didik, sehingga mereka yang memiliki prestasi dan berdomisili di daerah pinggiran menjadi tertutup untuk menyekolahkan anaknya di sekolah yang dipandang favorit, karena di luar zona. Hal ini sejalan dengan pernyataan salah satu informan, bahwa pola zonasi tidak memberikan kesempatan yang sama kepada calon peserta didik untuk berkompetisi secara akademik, walaupun kesempatan ini ada, tapi kuota jalur prestasi sangat sedikit, yaitu hanya $5 \%$, sangat banyak dengan pertimbangan jarak rumah dengan sekolah, sekitar $90 \%{ }^{7}$

Masyarakat beranggapan kebijakan zonasi kurang memberi kesempatan kepada masyarakat luas, terutama yang tidak satu zona dengan sekolah yang dipandang favorit, menutup kesempatan calon peserta didik baru yang berprestasi untuk berkompetisi, karena mereka pasti akan kalah bersaing dengan anak yang prestasi rendah, tapi lebih dekat jarak rumah dengan sekolah yang dipandang favorit. Hal ini selaras dengan apa yang dinyatakan oleh salah satu informan, kebijakan zonasi ini, menjadikan keinginan masyarakat menjadi terabaikan, sehingga mereka terpaksa memilih sekolah yang menurut mereka dipandang tidak bagus yang ada pada zonanya. Masyarakat hanya diberi kesempatan memilih sekolah yang ada pada zonanya, padahal menurut mayarakat, sekolah itu bukan sekolah yang diinginkan oleh anak-anaknya. Pola zonasi yang digunakan ini, tidak memberikan keleluasaan kepada masyarakat untuk memilih sekolah, pasti masyarakat memilih

\footnotetext{
${ }^{6}$ Yuliana Tri Wulandari anggota masyarakat dari Teja Timur kecamatan Pamekasan, wawancara, (18 April 2019)

${ }^{7}$ Hosnul Hotimah anggota masyarakat dari Jalmak kecamatan Pamekasan, wawancara, (20 April 2019)
} 
sekolah bagi anaknya, sekolah yang dipandang bagus dan berkualitas, pola zonasi tidak berkeadilan. Makanya masyarakat kurang setuju dengan pola zonasi ini. ${ }^{8}$

Pandangan masyarakat Pamekasan yang kurang setuju dengan kebijakan zonasi ini, karena mereka memandang kebijakan zonasi tidak menguntungkan kepada anak yang pintar dan memiliki prestasi tinggi untuk melanjutkan pada sekolah yang dianggap berkualitas, karena bisa jadi mereka yang ujian nasional tinggi kalah bersaing dengan anak yang memiliki nilai ujian nasional lebih rendah, tapi jarak tempat tinggal dengan sekolah berkualitas itu lebih dekat. Sesuai dengan apa yang ditegaskan oleh salah satu informan, bahwa kebijakan zonasi ini, kurang disosialisasikan kepada masyarakat, masyarakat menjadi tidak utuh memahami maksud kebijakan ini, ada keterkejutan yang kurang baik dirasakan oleh masyarakat, sehingga tidak terlalu salah bagi masyarakat kalau menyikapi tidak setuju. Karena kurangnya pemahaman yang utuh tentang kebijakan zonasi ini, masyarakat hanya merasakan, ada pembatasan, ada keterpaksaan untuk ikut pada kebijakan zonasi itu. Pola ini tidak berkeadilan, ada diskriminasi, tidak memberi kesempatan secara leluasa memilih sekolah terutama yang dipandang berkualitas oleh masyarakat. Pola zonasi kurang mendidik kepada masyarakat, pemerintah terlalu cepat menentukan suatu kebijakan tanpa diiringi waktu yang cukup untuk disosialisasikan kepada masyarakat akan pentingnya pemberlakukan zonasi. ${ }^{9}$

Kebijakan zonasi kurang memberikan kebebasan kepada masyarakat ketika akan memilih dan menentukan sekolah bagi anaknya. Kebebasan masyarakat menjadi terbatas. Masyarakat tidak leluasa memilih sekolah bagi anaknya sesuai dengan keinginan dan kemauannya. Masyarakat kecewa dengan kebijakan ini, karena membatasi kemauan masyarakat. Hal ini nampak dari pernyataan informan, zonasi sebagai suatu kebijakan baru pemerintah dalam dunia pendidikan, kurang memberikan penghargaan pada masyarakat untuk memilih sekolah yang dipandang unggul, bagaimanapun juga, masyarakat pasti menginginkan anaknya dapat melanjutkan pendidikan yang lebih tinggi pada sekolah yang dianggap unggul dan berkualitas. Oleh karena itu, masyarakat kurang setuju dengan kebijakan zonasi ini. ${ }^{10}$

Masyarakat Pamekasan menganggap, pola zonasi ini, membatasi keinginan masyarakat untuk memilih sekolah yang diinginkan. Masyarakat pasti menginginkan anaknya dapat melanjutkan pendidikan pada sekolah yang baik, yang dipilih masyarakat, sekolah yang berkualitas. Pola zonasi kurang memberikan makna yang berarti bagi masyarakat. Setiap masyarakat pasti punya keinginan dan kemauan menyekolahkan anaknya pada sekolah yang berkualitas. Sekolah yang berkualitas umumnya ada di perkotaan, sekolah berkualitas pasti diyakini dan dipandang oleh masyarakat sebagai sekolah favorit. Umumnya sekolah favorit lebih dulu ada dibandingkan sekolah lain yang dianggap tidak favorit. Hal ini, ditegaskan oleh salah satu informan, zonasi yang dijadikan kebijakan dalam penerimaan peserta didik baru, kurang memberikan kesempatan yang seluas-luasnya kepada masyarakat yang ada di pinggiran kota, sebab memang sekolah yang dipandang favorit oleh masyarakat, pasti ada di jantung kota, sementara masyarakat yang berdomisili di jantung kota pasti dari ekonomi menengah ke atas, sehingga mereka lebih banyak diuntungkan dengan kebijakan ini. Sementara masyarakat yang ada di pinggiran, bahkan di pelosok yang punya prestasi baik tidak bisa berkompetisi secara akademik karena ada di luar zona. ${ }^{11}$

Pandangan masyarakat, zonasi justru akan melahirkan diskriminasi baru di kalangan masyarakat, karena pada kenyataannya, sekolah yang dipandang favorit oleh masyarakat, pasti ada di

\footnotetext{
${ }^{8}$ Moh. Sidi anggota masyarakat dari Kangenan kecamatan Pamekasan, wawancara, (22 April 2019)

${ }^{9}$ Mar'atul Mahmudah orang tua siswa di SMAN 1 Pamekasan, wawancara, (23 April 2019)

${ }^{10}$ Siti Fadilah orang tua siswa di SMPN 1 Pameakasan, wawancara, (24 April 2019)

${ }^{11}$ Hasanuddin anggota masyarakat dari Bettet kecamatan Pamekasan, wawancara, (27 April 2019)
} 
jantung kota, dan masyarakat yang tempat tinggalnya ada di jantung kota, pasti masyarakat yang tingkat ekonominya menengah ke atas, sehingga sekolah yang dipandang favorit oleh masyarakat, didominasi oleh anggota masyarakat yang terdekat di sekitarnya yang pada umumnya dari kalangan masyarakat yang tingkat ekonominya menengah ke atas. Masyarakat yang berdomisili di daerah pinggiran kota, pasti tertutup kesempatan untuk melanjutkan ke sekolah yang dipandang favoritsebab sekolah favorit itu pasti ada di jantung kota. Masyarakat dari ekonomi menengah ke bawah ada pada zona sekolah pinggiran yang dipandang tidak unggul.

Kebijakan zonasi yang diberlakukan, kurang baik dan menimbulkan kekecewaan di kalangan masyarakat, karena zonasi ini hanya menguntungkan masyarakat yang dekat dengan sekolah favorit, walapun mereka tidak memiliki kemampuan intelektual bagus. Mereka dengan mudah diterima di sekolah favorit yang dekat dengan rumah tempat tinggalnya. Sekolah favorit didominasi masyarakat kota yang karena domisilinya lebih dekat, bukan karena prestasi. Kebijakan zonasi ini menutup peluang anak untuk melanjutkan ke sekolah favorit yang ada di jantung kota, karena mereka ada di daerah pinggiran tidak masuk pada zona sekolah favorit, padahal andaikata tidak diberlakukan zonasi, mereka bisa bersaing dan kemungkinan bisa diterima di sekolah favorit, karena memiliki prestasi di atas rata-rata. Zonasi yang dijadikan pijakan ini, tidak menguntungkan kepada masyarakat yang bertempat tinggal di luar perkotaan. Pasti zona yang terdekat dari rumah mereka adalah sekolah yang tidak unggul, padahal andaikata tidak ada kebijakan ini, mereka bisa bersaing dengan anak yang dekat dengan sekolah unggul yang ada di jantung kota, karena memiliki kemampuan intelektual di atas rata-rata.

Berdasarkan pengamatan peneliti terhadap perkataan mereka ketika diwawancarai, mimik bicara mereka menampakkan kurang setuju dengan kebijakan zonasi ini. Mimik bicara mereka, mengesankan kecewa, tidak suka, dan tidak suka terhadap pola zonasi. Tersirat makna dari mimik bicara mereka bahwa pola zonasi menutup kesempatan anak-anaknya melanjutkan pendidikan di sekolah yang dipandang favorit dan berkualitas. Mereka merasa risau dan tidak puas dengan kebijakan itu, sebab sebelum zonasi ini diberlakukan, rata-rata anak-anak mereka bisa bersaing dan diterima di sekolah favorit. Mereka bangga dengan prestasi itu. Dan anggapan masyarakat, ketika anaknya sekolah pada lembaga pendidikan yang dipandang favorit, untuk melanjutkan pada pendidikan yang lebih tinggi, pasti juga lebih mudah diraih dan diwujudkan diterima di lembaga pendidikan yang juga favorit. Dan dari realitas yang peneliti amati, rata-rata anak mereka yang sudah kuliah di PTN yang dipandang favorit, pada umumnya alumni SMAN 1 Pamekasan dan SMAN 3 Pamekasan, dan SMP nya kalau tidak SMPN 1 Pamekasan atau SMPN 2 Pamekasan. Bahkan ada fenomena menarik di kalangan masyarakat yang memiliki tingkat ekonomi menengah ke atas, karena di luar zona sekolah favorit, mereka memilih lembaga pendidikan pesantren/lembaga pendidikan Islam di luar madura yang memiliki lembaga pendidkan formal yang unggul dan berkualitas, dan dipandang sebagai alternatif pilihan terbaik bagi masa depan anak-anak mereka, termasuk lembaga pendidikan Islam yang ada di Pamekasan, animo orang tua peserta didik dan masyarakat semakin tinggi, seperti SMP Plus Nurul Hikmah kebanjiran calon peserta didik baru di luar kouta seperti biasanya sebelum zonasi ini diberlakukan. Dan termasuk MTsN dan MAN yang ada di kecamatan kota Pamekasan juga kebanjiran calon peserta didik terutama pada penerimaan peserta didik baru kelas unggulan, MTsN dan MAN belum memberlakukan pola zonasi. Atau ke pondok pesantren atau lembaga pendidikan Islam di luar Madura yang memiliki sekolah yang sudah diakui unggul dan berkualitas, seperti Ponpes Amanatul Ummah Pacet Mojokerto, Ponpes Bumi Sholawat Sidoarjo, bahkan ada yang ke Tazkiyah serta Al-Izzah di Malang dan lain sebagainya. ${ }^{12}$

12 Observasi terhadap pandangan dan sikap masyarakat, (18 - 30 April 2019) 
Di samping itu, ada juga beberapa respon masyarakat Pamekasan yang menyatakan setuju terhadap pola penerimaan peserta didik baru berbasis zonasi. Mereka berpandangan, dengan zonasi akan bisa menghilangkan dikriminasi dalam pendidikan, yaitu adanya sekolah favorit dan tidak favorit. Cuma memang seharusnya pemerintah harus lebih sering mensosialisasikan kebijakan baru ini kepada masyarakat, agar tidak ada keterkejutan masyarakat. Semua sekolah sudah terpetakan berdasarkan zona, sehingga anak yang berprestasi menyebar pada semua sekolah, sesuai dengan apa yang dikatakan oleh informan, kebijakan zonasi ini cukup bagus dan adil. Ini sebagai upaya pemerintah untuk memeratakan pendidikan kepada semua masyarakat, sekaligus akan menghilangkan image masyarakat yang membedakan adanya sekolah unggul dan tidak unggul. Kebijakan zonasi sebagai suatu kebijakan baru dari pemerintah cukup baik. Apabila ini berjalan lancar dapat menghilangkan pandangan masyarakat terhadap adanya sekolah favorit dan tidak favorit. Akses pendidikan bisa merata kepada masyarakat. ${ }^{13}$

Respon masyarakat yang setuju pada zonasi ini, karena mereka memandang akan terjadi pemerataan anak yang berprestasi. Mereka yang berprestasi tidak menyatu di satu sekolah. Dan pada akhirnya akan menghilangkan predikat sekolah favorit dan tidak favorit. Zonasi ini pada dasarnya ingin memberikan kesadaran kepada masyarakat untuk menyekolahkan anaknya pada lembaga pendidikan yang lebih dekat dengan rumahnya. Sehingga orang tua dapat bersinergi dengan sekolah untuk melakukan pemantauan terhadap aktivitas dan perilaku peserta didik.

Dengan demikian dapat ditegaskan, pada umumnya masyarakat Pamekasan kurang setuju dengan pola zonasi, karena beberapa alasan yaitu; zonasi mengeleminasi dan membatasi kebebasan masyarakat untuk memilih sekolah, pola zonasi mengabaikan kompetisi akademik, zonasi tidak menjunjung tinggi prinsip keadilan, karena menutup peluang calon peserta didik berprestasi yang dari pinggiran bahkan dari desa di luar zona untuk bersaing di sekolah yang ada di jantung kota, walaupun di Permendikbud 51 tahun 2018 diatur, kuotanya sangat kecil, yaitu 5\% untuk jalur prestasi, zonasi kurang sejalan dengan keinginan dan kemauan masyarakat, masyarakat pasti menginginkan anaknya mengenyam pendidikan di sekolah yang unggul dan berkualitas, serta zonasi melahirkan diskriminasi baru sebab sekolah unggul dan berkualitas ada di jantung kota, sehingga peserta didiknya didominasi oleh masyarakat kota yang jarak rumah dengan sekolah lebih dekat.

Tetapi ada juga sebagian kecil masyarakat yang menyatakan setuju, dengan beberapa alasan, yaitu; memberi kesempatan yang sama kepada semua masyarakat untuk mendapatkan pelayanan pendidikan yang merata, memeratakan calon peserta didik yang berprestasi kepada semua sekolah, tidak menyatu di satu sekolah yang dipandang favorit oleh masyarakat, sebagai suatu upaya untuk menghilangkan predikat sekolah favorit dan tidak favorit, bahkan menjadikan semua sekolah unggul dan berkualitas, dan sebagai suatu proses untuk menumbuhkan dan mengembangkan kepercayaan masyarakat terhadap pengelolaan lembaga pendidikan untuk melahirkan profil lulusan yang berkualitas.

Respon masyarakat yang tidak setuju terhadap pola penerimaan peserta didik baru berbasis zonasi, mereka kecewa dengan zonasi tersebut, terutama dengan dihilangkannya sekolah favorit yang sebelumnya diperebutkan dengan sistem kompetisi. Mereka merasa tidak rela kalau predikat sekolah favorit itu dihilangkan, karena memang pandangan itu sudah mengakar kuat di hati masyarakat. Memang ada kecenderungan keinginan masyarakat menyekolahkan anaknya dekat rumah, tapi berkualitas. Pertimbangan mereka dekat rumah terkait dengan alasan keamanan dan kemudahan orang tua mengawasi mereka, dan berkualitas menjamin masa depan anak mereka terutama untuk melanjutkan pada jenjang yang lebih tinggi yang juga berkualitas lebih mudah diterima.Ini semua

\footnotetext{
13 Agus Supriyadi anggota masyarakat kota Pamekasan, wawancara, (1 Mei 2019)
} 
realitas penyelenggaraan pendidikan yang terjadi, oleh karena itu, pemerintah berupaya untuk mengurangi bahkan menghilangkan predikat sekolah favorit dan tidak favorit. Upaya itu dengan kebijakan pola zonasi dalam penerimaan peserta didik baru. Dengan zonasi diharapkan dapat menghilangkan sekolah favorit dan tidak favorit sekaligus sebagai upaya memeratakan pendidikan itu. Sekolah favorit seharusnya tidak ada. Diharapkan seluruh sekolah favorit. Sekolah di mana pun fasilitas dan kualitas yang didapat sama rata.

Memang sejatinya kebijakan zonasi ini, merupakan upaya pemerintah pusat untuk memeratakan fasilitas dan kualitas layanan pendidikan. Memenuhi hak-hak memperoleh pendidikan semua anak usia sekolah. Sudah saatnya mengikis dan menghilangkan dikotomi yang ekstrem. Antara sekolah favorit dan sekolah pinggiran. Antara sekolah yang dicitrakan buruk karena raw input peserta didik dari kelompok anak-anak nakal, bodoh, serta tidak berprestasi dan sekolah yang raw input dari anak yang pinter, inovatif, serta berprestasi. Pola zonasi diharapkan dapat menghilangkan eksklusivisme seperti itu. Inklusivisme harus ditumbuhsuburkan. Orang tua tidak perlu khawatir dan ragu berlebihan, bahwa peserta didik yang pintar bakal tertular kenakalan. Orang tua harusnya bersyukur jika peserta didik yang pandai mampu menjadi inspirasi teman-temannya. Iklim demokratis akan tercipta di lingkungan sekolah. Peserta didik diajak mampu menerima keberagaman latar belakang. Belajar menghargai perbedaan potensi.

Tugas sekolah adalah menciptakan lingkungan dan komunitas yang demokratis. Di dalamnya terkandung tugas mulia guru sebagai pendidik. Guru adalah fasilitator, orang tua, bahkan teman peserta didik. Guru sebagai pembelajar dan peserta didik sebagai pemelajar terdorong untuk berbagi tanggung jawab, tolong menolong, sekaligus saling berempati.

Pola zonasi ini, juga dipandang oleh masyarakat tidak berkeadilan. Zonasi menutup peluang untuk berkompetisi secara akademik. Masyarakat yang sudah mulai lama mempersiapkan anaknya agar diterima di sekolah yang berkualitas dan favorit menjadi terabaikan, bahkan ditutup rapat-rapat. Upaya masyarakat dengan tidak mencukupkan proses belajar anaknya hanya di sekolah menjadi tidak dihargai. Masyarakat yang sudah mempersiapkan anak-anaknya dengan diikutkan bimbingan belajar pada lembaga bimbingan belajar yang dipandang berkualitas dengan berani mengeluarkan biaya yang tidak murah, dianggap menjadi tidak ada gunanya. Semua upaya yang dilakukan oleh masyarakat menjadi tidak penting dengan kebijakan pola zonasi ini. Masyarakat berpandangan bahwa hanya sekolah yang berkualitas yang dapat menjanjikan masa depan yang cemerlang bagi anak-anaknya. Masyarakat berharap banyak pada sekolah yang unggul. Keyakinan masyarakat terhadap sekolah favorit sudah mengakar kuat. Hal ini wajar karena banyak alasan yang dijadikan indikator, diantaranya; seberapa besar sekolah itu dapat mengantarkan peserta didiknya dapat diterima di lembaga pendidikan yang lebih tinggi yang dipandang favorit dan berkualitas oleh masyarakat, adanya pengakuan sejak lama dari masyarakat karena sekolah itu lebih dulu berdiri, seberapa banyak sekolah itu dapat mengantarkan peserta didiknya diterima di program studi yang dianggap favorit oleh masyarakat, serta seberapa banyak alumni sekolah itu menjadi tokoh penting baik tingkat lokal, regional, nasional, bahkan internasional.

"Sekolah favorit menjadi tumpuan dan incaran orang tua peserta didik. Mereka beranggapan dengan bisa masuk di sekolah favorit, ke depan sang anak juga bisa melanjutkan ke jenjang pendidikan yang lebih tinggi dan favorit pula. Jadilah labelisasi sekolah favorit dan nonfavorit berkembang. Ujungnya, sekolah favorit menjadi rebutan. Sebaliknya, sekolah nonfavorit kesulitan mendapat peserta didik. Sedikitnya ada tiga hal yang ingin dicapai pemerintah dengan memberikan pelayanan paripurna di bidang pendidikan. Yakni, menyangkut ketersediaan, keterjangkauan, dan kualitas. Berbagai kebijakan selalu berpijak kepada tiga hal tersebut tak terkecuali kebijakan peneriman peserta didik baru pola zonasi. Kebijakan zonasi ini, sebenarnya bertujuan memeratakan 
kualitas sekolah dan diharapkan bisa menghilangkan dikotomi sekolah favorit dan nonfavorit. Pola tersebut menjadi kompleks karena melakukan perubahan fundamental dan mengubah tatanan serta perspektif para calon peserta didik. Pemahaman tentang konsep sekolah favorit dan nonfavorit beserta kebanggaan yang menyertainya, menjadi goyah. Sekolah yang sudah terlanjur berlabel favorit harus siap berbagi dengan sekolah lain nonfavorit. Dan mungking orang tua peserta didik akan berpikir sedikit lebih keras untuk memilih wilayah tempat tinggal yang prospektif untuk pendidikan anaknya. Harus diakui bahwa kebijakan ini adalah langkah strategis untuk mewujudkan pendidikan yang merata dan berkualitas, sudah selayaknya kebijakan zonasi diapresiasi dan diterima. Ke depan kebijakan yang harus mengikuti setelah penerimaan peserta didik baru zonasi ini adalah redistribusi guru, baik secara jumlah maupun kualitas dan penerapan kebijakan terkait tentang penataan sekolah". ${ }^{4}$

Memang ada masyarakat yang mendukung kebijakan zonasi ini, tetapi sebagian kecil terutama masyarakat sekitar yang memiliki anak yang secara akademik memiliki prestasi rendah. Dengan kebijakan ini, mereka menyikapi sangat setuju. Bagi mereka sangat menguntungkan. Ketika pola zonasi ini belum diberlakukan, mereka tidak pernah punya kesempatan sekolah di lembaga pendidikan yang dipandang favorit dan berkualitas oleh masyarakat yang berdekatan dengan rumahnya. Mereka kalah bersaing, kompetisi akademik menjadi penentu, pasti yang lolos kompetisi akademik adalah mereka yang memiliki prestasi bagus dan unggul. Dengan kebijakan pola zonasi ini, calon peserta didik yang berprestasi akademik bisa dikalahkan oleh calon peserta didik yang tidak memiliki prestasi akademik, karena mereka dikalahkan oleh jarak rumah dengan sekolah. Pasti yang lebih besar diterima di sekolah adalah calon peserta didik yang lebih dekat jarak rumah dengan sekolah, walaupun prestasi akademik mereka rendah.

Pola zonasi yang mejadi kebijakan baru dari pemerintah, seharusnya diinformasikan secara memadai dan leluasa kepada masyarakat. Informasi kepada masyarakat bisa dilakukan oleh sekolah. Ketika informasi yang diberikan sekolah kepada masyarakat secara detail dan apa tujuan yang diinginkan, diharapkan muncul respon positif terhadap sekolah, termasuk juga tentang kebijakan baru dari pemerintah, seperti kebijakan zonasi ini. "Respon positif ini dipandang sebagai suatu citra yang menimbulkan sikap positif yang akan menjelma menjadi dukungan terhadap penyelenggaraan pendidikan termasuk kebiajakan baru di sekolah. Atas hubungan yang erat dan komunikatif antara sekolah dengan masyarakat lebih mudah memperbaiki pendidikan, sebab masyarakat sudah mengerti akan kehadiran dan peran sekolah serta memberi dukungan yang diperlukan". ${ }^{15}$ Pemberian informasi secara memadai menjadi penting terutama berkaitan dengan suatu kebijakan baru yang akan dilakukan oleh pemerintah. Kebijakan baru perlu waktu yang memadai untuk melakukan sosialisasi kepada masyarakat, sehingga masyarakat tidak terkejut, yang pada akhirnya akan merespon negatif terhadap kebijakan baru itu. ${ }^{16}$

"Sebenarnya masyarakat memiliki harapan besar kepada sekolah. Sekolah sebagai suatu institusi penyelenggara pendidikan haruslah bersenergi dengan keinginan dan kemauan masyarakat. Termasuk kebijakan baru dalam pendidikan, perlu mempertimbangkan kepentingan dan kebutuhan masyarakat". ${ }^{17}$ Masyarakat perlu diberi pemahaman yang utuh tentang kebijakan baru dalam dunia pendidikan. Ketika masyarakat dilibatkan aktif dalam pemberlakuan kebijakan baru dalam

\footnotetext{
${ }^{14}$ Sukemi, PPDB: Upaya Pemerataan Pendidikan, (Jawa Pos, Kamis, 20 Juni 2019), 4

${ }^{15}$ Nanang Fattah, Analisis Kebijakan Pendidikan, (Bandung: Remaja Rosdakarya, 2014), 19

16 Aris Nurlailiyah, "Analisis Kebijakan Sistem Zonasi Terhadap Perilaku Siswa di Yogyakarta”, Jurnal Realita, Vol. 17 No.1, (Januari 2019), 20

${ }_{17}$ Tiara Anggia Dewi, "Pengaruh Profesionalisme Guru Dan Motivasi Kerja terhadap Kinerja Guru Ekonomi SMA Se Kota Malang", Jurnal Pendidikan Ekonomi, Vol. 3 No. 1, (2005), 27
} 
pendidikan, diharapkan masyarakat menyikapi dengan respon positif. Respon positif masyarakat melahirkan citra dan sikap positif kepada sekolah, hal ini penting, sebab pada kenyataan bahwa orang tua dan masyarakat pada umumnya tidak mampu membina dan memberikan pendidikan kepada anak-anaknya agar berkembang dengan seutuhnya tanpa bantuan dan kehadiran sekolah. Para orang tua tidak memiliki semua ilmu pengetahuan yang patut dikuasai oleh anak-anaknya dalam usaha mengembangkan diri. Para orang tua juga tidak mempunyai keterampilan yang memadai untuk membina perkembangan anak-anaknya. Masyarakat memiliki sikap dan pandangan, bahwa sekolah sebenarnya merupakan sarana yang sangat efektif untuk mengembangkan potensi yang dimiliki oleh anak-anaknya, karena itu masyarakat berpartisipasi dan setia untuk memberikan dukungan terhadap penyelenggaraan pendidikan di institusi pendidikan.

Tuntutan dan penciptaan respon baik masyarakat ini, harus disikapi positif dan serius oleh sekolah, karena itu seyogianya sekolah responsif dan merefleksikan kebutuhan, kemauan, dan keinginan masyarakat. Sekolah tidak mejadi menara gading. Kebutuhan dan keinginan masyarakat perlu diakomudasikan dalam program pendidikan di sekolah. Sekolah menjadi agen of social change. Respon positif dari masyarakat penting diperhatikan oleh kepala sekolah dan para guru. Respon positif akan menumbuhkan dan mengembangkan hubungan mutualistik antara sekolah dengan masyarakat. Hubungan baik ini akan mewujudkan dukungan kuat dari masyarakat, dan akan melahirkan kepercayaan masyarakat terhadap sekolah tersebut semakin tinggi. Ketika kepercayaan masyarakat semakin tinggi, maka pasti sekolah itu menjadi incaran semua masyarakat untuk menyekolahkan anaknya. Sudah tentu, sekolah tidak akan pernah kesulitan mendapatkan calon peserta didik baru, karena semua masyarakat mengharap untuk memiliki kesempatan bagi anakanaknya mengeyam pendidikan di sekolah yang mendapat kepercayaan tinggi dari masyarakat. Pasti sekolah dengan dukungan masyarakat yang kuat, sekolah itu dipandang oleh masyarakat sebagai sekolah yang unggul, favorit, idola, dan berkualitas. Semua masyarakat berkeinginan untuk dapat menyekolahkan anak-anaknya pada sekolah dimaksud. ${ }^{18}$

Sudah tentu keberadaan seorang kepala sekolah menjadi penting dalam rangka memberikan informasi sedetail-detailnya terutama yang mencakup kebijakan baru dalam dunia pendidikan. "Kepala sekolah sebagai pengelola, dituntut untuk memiliki kualifikasi dan kompetensi sebagaimana yang ditegaskan dalam Permendiknas nomor 13 tahun 2007 tentang standar kepala sekolah/madrasah. Dalam Permendiknas itu, ditegaskan kompetensi yang harus dimiliki oleh kepala sekolah mencakup; kompetensi kepribadian, kompetensi manajerial, kompetensi kewirausahaan, kompetensi supervisi, dan kompetensi sosial. Kepala sekolah sebagai pengelola pada lembaga pendidikan akan berhubungan langsung dengan masyarakat. Dengan demikian kepala sekolah dituntut untuk memiliki kreativitas komunikasi yang baik dengan masyarakat. Ketika kepala sekolah menjalankan tugasnya, dibutuhkan etika dengan harapan dapat memiliki perilaku, sikap, dan sifat yang baik". ${ }^{19}$ Kepala sekolah harus memiliki kompetensi mengelola sekolah yang bagus. Pengelolaan sekolah yang dilakukan secara profesional, akan mewujudkan sekolah berkualitas. Hanya pengelolaan yang profesional yang dapat mewujudkan sekolah unggul dan difavoritkan oleh masyarakat. Sekolah unggul dan berkualitas, diindikasikan; dikelola oleh kepala sekolah yang punya kompetensi akademik dan manajerial baik, proses pembelajaran dilakukan oleh guru yang memiliki kompetensi tinggi, didukung oleh fasilitas belajar yang memadai, serta tercipta iklim dan suasana lingkungan belajar yang menarik dan menyenangkan.

\footnotetext{
${ }^{18}$ Bedjo Sujanto, Pengelolaan Sekolah Permasalahan dan Solusi, (Jakarta: Bumi Aksara, 2018), 59

${ }^{19}$ Rasdi Ekosiswoyo, “Kepemimpinan Kepala Sekolah Yang Efektif Kunci Pencapaian Kualitas Pendidikan”, Jurnal Ilmu Pendidikan, Jilid 14 No. 2, (Juni, 2007), 80
} 


\section{Respon Sekolah}

Sebenarnya respon sekolah terhadap kebijakan zonasi di Pamekasan dapat dikelompokkan menjadi dua, ada yang setuju dan sebagian besar tidak setuju. Sekolah yang memberikan respon setuju, memiliki pandangan bahwa pola zonasi yang diberlakukan oleh pemerintah adalah baik, sebab hal ini sebagai suatu upaya untuk memeratakan semua sekolah menjadi unggul dan berkualitas. Anak yang berprestasi tidak berkumpul di satu sekolah yang dipandang favorit oleh masyarakat. Walaupun demikian, jalur prestasi tetap dipertahankan, bahkan prosentasi perlu ditambah tidak hanya $5 \%$, tetapi bisa $20 \%$. Sebagaimana yang dikatakan oleh beberapa informan, zonasi yang menjadi kebijakan pemerintah adalah baik, pola zonasi dilakukan dalam rangka memeratakan kualitas peserta didik dan peningkatan kualitas sekolah. Anak yang berkualitas tidak menumpuk pada satu sekolah. Ada pemerataan anak yang berkualitas menyebar kepada semua sekolah. Pola zonasi yang menjadi kebijakan pemerintah, berdampak baik terutama pada sekolah yang sementara ini dipandang oleh masyarakat tidak berkualitas. Akan ada pemerataan kualitas pendidikan pada semua sekolah. Memang kebijakan ini dalam waktu dekat belum terasa manfaat yang dirasakan, tetapi pada akhirnya akan dirasakan manfaatnya oleh semua masyarakat. ${ }^{20}$

Beberapa informan lain menyatakan, zonasi yang diberlakukan oleh pemerintah adalah cukup baik, sebab dengan kebijakan ini, dimaksudkan ingin memeratakan calon peserta didik yang berprestasi tidak menumpuk di satu sekolah, tetapi menyebar pada semua sekolah, tetapi perlu dilakukan pembenahan lebih lanjut, terutama pada kouta jalur prestasi perlu ditambah. ${ }^{21}$

Kebijakan zonasi yang diberlakukan oleh pemerintah dimaksudkan secara perlahan dapat mengurangi tingkat persaingan tidak sehat antarsekolah. Saling berebut peserta didik dengan diimingi dapat seragam dan buku gratis, bahkan saling menjelekkan antarsekolah. Pola zonasi mengatur kedekatan rumah dengan sekolah, sehingga di luar zona, calon peserta didik tidak bisa mendaftar, kecuali menggunakan jalur prestasi yang hanya ditentukan 5\%. Zonasi yang diterapkan pemerintah sudah cukup bagus. Pola zonasi ini memberi peluang kepada anak memilih sekolah yang paling dekat dengan rumah. Cuma memang dalam pelaksanaan, perlu ada komitmen yang tinggi di kalangan sekolah, tidak menerima calon peserta didik di luar zona, walaupun kenyataannya anak yang mendaftar masih kurang dari pagu yang sudah ditentukan. Hal ini sejalan dengan apa yang dikatakan oleh beberapa informan, pola zonasi yang diberlakukan oleh pemerintah dimaksudkan untuk menghilangkan image masyarakat terhadap sekolah unggul dan tidak unggul. Walaupun demikian, upaya ini berat dan butuh waktu agak lama untuk dapat mewujudkan cita-cita ini, karena image itu sudah turun temurun dan bahkan sudah mendarah daging di kalangan masyarakat. ${ }^{22}$

Respon sekolah di Pamekasan yang setuju dengan pola zonasi berpandangan, kebijakan zonasi akan meratakan kualitas pendidikan. Hal ini sejalan dengan apa yang dikatakan oleh Azizah bahwa program zonasi merupakan salah satu kebijakan pemerintah untuk pemerataan pendidikan. Sekolah dapat bersaing untuk memiliki kualitas yang baik dan tidak kalah dengan sekolah yang sudah dianggap favorit. Zonasi ini memberikan akses yang seluas-luasnya bagi sekolah dan peserta didik untuk mengembangkan kualitasnya. ${ }^{23}$

Di samping itu, respon sekolah di Pamekasan banyak yang menyatakan tidak setuju dengan pola zonasi, terutama di kalangan peserta didik, selama peneliti mewawancarai mereka hampir pada umumnya peserta didik yang ada di SMPN dan SMAN di kecamatan kota Pamekasan menyatakan

\footnotetext{
20 Abd. Aziz kepala SMAN 3 Pamekasan, Kamaruddin kepala SMAN 2 Pamekasan, wawancara, (8 Mei 2019)

${ }^{21}$ Eva Yusnita guru SMAN 2 Pamekasan Hidayat Santoso guru SMPN 8 Pamekasan, wawancara, (10 Mei 2019)

22 Jamil kepala SMPN 8 Pamekasan, Abdurrahman kepala SMPN 3 Pamekasan, wawancara, (13 Mei 2019)

23 Azizah Arifinna Safarah, "Program Zonasi di Sekolah Dasar sebagai Upaya Pemerataan Kualitas Pendidikan di Indonesia", Jurnal Lentera Pendidikan, Vol. 21 No. 2, (Desember 2018), 212
} 
tidak setuju. Sebagaimana dikatakan oleh beberapa informan, zonasi yang dijadikan acuan dalam penerimaan peserta didik baru cukup membingungkan dan kami kurang setuju. Pola zonasi ini menutup kesempatan kami memilih sekolah yang kami inginkan. Sudah pasti, kami menginginkan sekolah yang unggul dan berkualitas. Walaupun sebenarnya kami, alhamdulillah sudah berkesempatan sekolah sesuai dengan keinginan kami. ${ }^{24}$ Memang kalau diamati secara cermat, peserta didik baru yang berprestasi yang ada di luar zona kalah bersaing dengan yang tidak berprestasi di dalam zona. Secara sikap dan perilaku mereka, masih tersirat ketidakpuasan karena tidak bisa bersaing secara akademik. Mereka kalah bersaing, hanya karena jarak rumahnya lebih jauh. Mereka terpaksa masuk di sekolah yang dipandang tidak favorit dan menjadi zona mereka. Di samping itu, ada beberapa sekolah yang dipandang favorit oleh masyarakat masih mempertahankan adanya kelas unggulan. Cuma karena memang raw-input sangat heterogen, tidak terisi oleh peserta didik yang memiliki kemampuan mengarah ke homogen. Kemampuan mereka sangat beragam, bahkan lebih banyak diisi oleh peserta didik yang memiliki kemampuan tidak unggul, sehingga suasana kelas unggulan tidak terlalu banyak perbedaan dengan kelas reguler. ${ }^{25}$

Pemberlakuan zonasi dalam penerimaan peserta didik baru membingungkan masyarakat. Mereka tidak leluasa dan tidak bebas memilih sekolah. Kebebasan masyarakat sangat dibatasi. Calon peserta didik tidak bisa berkompetisi secara akademik, padahal sebenarnya mereka cukup lama mempersiapkan diri termasuk intens mengikuti privat di lembaga bimbingan belajar berkualitas, demi bisa bersaing untuk diterima di sekolah favorit. Ternyata persaingan hanya didasarkan pada kedekatan rumah dengan sekolah. Ini sangat merugikan. Hal ini dikatakan oleh beberapa informan, kebijakan zonasi sebagai kebijakan baru pemerintah, sebenarnya kurang memberikan kebebasan bahkan mengabaikan hak warga masyarakat untuk mendapat pelayanan pendidikan yang berkualitas. Semua masyarakat menginginkan sekolah yang berkualitas. Ketika masyarakat yang ada di daerah pinggiran dan berprestasi, pasti tidak akan bisa mengakses sekolah yang berkualitas karena di luar zona, walaupun memang ada jalur prestasi, tapi kuotanya sangat sedikit, hanya $5 \%{ }^{26}$

Kebijakan zonasi dapat dipandang sebagai kebijakan penyeragaman secara nasional, dan kebijakan ini sebenarnya kurang selaras dengan semangat reformasi pada tuntutan adanya otonomi pendidikan. Di kalangan guru banyak juga yang kurang setuju. Tetapi karena sudah menjadi kebijakan pemerintah, mau tidak mau, mereka harus mengikuti. Status mereka sebagai aparatur sipil negara harus mengamankan dan melaksanakan kebijakan pemerintah dalam bidang pendidikan. Tetapi harapan mereka, ke depan perlu ada regulasi baru yang memberikan porsi lebih banyak pada jalur prestasi. Pola zonasi memberikan kesan ada keterbatasan calon peserta didik untuk memilih sekolah sesuai dengan keinginan mereka. Mereka yang kebetulan ada di daerah pinggiran, walaupun punya prestasi dengan nilai ujian nasional tinggi menjadi tersisihkan oleh kompetitornya hanya karena lebih dekat jaraknya dengan sekolah yang diinginkan.

Zonasi tidak menjamin kualitas calon peserta didik, sebab jalur zonasi koutanya paling banyak, yaitu $90 \%$, sementara jalur prestasi hanya $5 \%$ dan jalur pindah tugas orang tua juga $5 \%$. Memang ketentuan ini berlaku secara nasional, sebenarnya menurut kami, ketentuan ini kurang sejalan dengan

\footnotetext{
${ }^{24}$ Rifqi Ramzi, Nur Syamsi Maulidi, Reza Murdani, siswa SMAN 1 Pamekasan, Rahmatullah Triyananda, Fidia Azizah, Dradora Giselza, siswa SMPN 2 Pamekasan, Erika Oktaviani, Rossa Indira, siswa SMPN 1 Pamekasan, wawancara, (13, 14, dan 15 Mei 2019)

${ }^{25}$ Observasi di sekolah, (13, 14, dan15 Mei 2019)

${ }^{26}$ Retno Widayanti, Sukinno, Nur Suharyati, guru di SMPN 1 Pamekasan, Suroso, Mustofa, Rudy Djoko P., guru di SMPN 2 Pamekasan, Riskiyah, Abd. Jamil, Nikmah, guru SMAN 3 Pamekasan, M. Syafii, Siti Romlah, Ina Sulistiani, guru SMAN 4 Pamekasan, Lilik Kusdawarti, Budhi Kuswanto, guru SMAN 2 Pamekasan, wawancara, (13, 18, 20 Mei 2019)
} 
amanat UU nomor 20 tahun 2003 yang menekankan pada adanya keleluasaan untuk melakukan pengelolaan pada tingkat satuan pendidikan. ${ }^{27}$

Dari hasil pengamatan peneliti, memang cukup banyak kepala sekolah di Pamekasan yang menunjukkan sikap kurang sependapat dengan pola zonasi ini. Cuma memang mereka sebagai jajaran teknis dan ujung tombak pendidikan dari pemerintah, walaupun pada dasarnya kurang sependapat, mereka tetap harus melakukan, karena ini juga sebagai bentuk loyalitas dan dedikasi mereka sebagai top leader pada satuan pendidikan yang diangkat oleh pemerintah. Kepala sekolah sebagai penanggung jawab penerimaan peserta didik baru, tetap mempersiapkan dan menjalankan tugas dengan tanggung jawab. Aktivitas kepala sekolah nampak sungguh-sungguh, ketika mempersiapkan kegiatan dimaksud dengan mengkoordinasikan dengan pihak terkait. ${ }^{28}$ Dan memang dalam "Undang-Undang nomor 20 tahun 2003 pada pasal 51 ayat 1, menegaskan bahwa pengelolaan satuan pendidikan anak usia dini, pendidikan dasar, dan pendidikan menengah dilaksanakan berdasarkan standar minimal dengan prinsip manajemen berbasis sekolah/madrasah". Pada dasarnya penerimaan peserta didik baru menjadi bagian dari porsi pengelolaan satuan pendidikan. Sehingga sebenarnya penerimaan peserta didik baru tidak perlu ada penyeragaman secara nasional.

Dapat ditegaskan respon sekolah di Pamekasan ada dua, sebagian besar tidak setuju, sebagian kecil menyatakan setuju. Sebagian besar tidak setuju, dengan beberapa alasan, yaitu; zonasi mengeleminasi dan membatasi sekolah mendapatkan calon peserta didik baru yang berkualitas, zonasi mengabaikan prestasi akademik calon peserta didik baru, walaupun di Permendikbud 51 tahun 2018 diatur jalur prestasi, koutanya sangat kecil, hanya 5\%, zonasi tidak menjunjung tinggi semangat reformasi, yaitu tuntutan pada penguatan otonomi pendidikan, sebab kebijakan zonasi diberlakukan secara nasional, tidak sejalan dengan amanat UU nomor 20 tahun 2003 pasal 51 ayat 1 yang menyatakan bahwa pengelolaan satuan pendidikan anak usia dini, pendidikan dasar, dan pendidikan menengah dilaksanakan dengan prinsip manajemen berbasis sekolah/madrasah dan kegiatan penerimaan peserta didik baru menjadi salah satu kegiatan dari pengelolaan satuan pendidikan, dan zonasi menciptakan pemetaan dan penentuan kelas semakin heterogen. Keadaan ini akan sedikit menyulitkan kepada guru sebagai ujung tombak pembelajaran untuk memberikan pelayanan prima kepada semua peserta didiknya.

Tetapi ada beberapa sekolah yang memberikan respon setuju dengan beberapa alasan, yaitu; zonasi memberi akses yang sama kepada calon peserta didik dalam zona untuk mendapatkan pelayanan pendidikan yang merata, zonasi memeratakan keunggulan dan kualitas pada semua sekolah, tidak menyatu pada satu sekolah, karena calon peserta didik yang beprestasi tidak menyatu di satu sekolah, tetapi menyebar pada semua sekolah, zonasi sebagai upaya untuk menghilangkan image dikotomis masyarakat terhadap sekolah unggul dan tidak unggul, perlu ada tambahan kouta jalur prestasi, minimal 20\%, dan zonasi mempercepat tercapainya standar minimal oleh semua satuan pendidikan sebagaimana yang telah ditentukan dalam standar nasional pendidikan.

Respon sekolah yang menyikapi positif, berpandangan bahwa pola zonasi bisa memunculkan pemerataan pendidikan dan mengikis persepsi tentang sekolah unggul dan tidak unggul. Pola zonasi akan memeratakan masukan/input pada sekolah. Anak yang berprestasi tidak menumpuk pada satu sekolah yang dipandang unggul. Ini sejalan dengan apa yang dikatakan oleh M. Alfan Alfian, "sebenarnya kebijakan zonasi yang dilakukan oleh pemerintah, memiliki landasan sosiologis. Realitas yang terjadi, masih adanya ketimpangan/kesenjangan pendidikan antardaerah. Kemudian belum

\footnotetext{
${ }^{27}$ Mohammad Zaini kepala SMPN 1 Pamekasan, Mustakim kepala SMPN 2 Pamekasan, Sulistiyawati kepala SMPN 5 Pamekasan, wawancara, (15 dan 21 Mei 2019)

${ }_{28}$ Observasi terhadap perilaku kepala sekolah, (15 dan 21 Mei 2019)
} 
meratanya kualitas dan kuantitas sekolah, khususnya dalam prasarana dan sarana serta guru. Juga masih adanya diskriminasi dan ketidakadilan terhadap akses serta layanan pendidkan sebagai layanan dasar yang wajib diberikan kepada seluruh warga negara". ${ }^{29}$

Dengan kebijakan zonasi ini akan memberi tantangan kepada sekolah terutama guru menghadapi keadaan peserta didik yang semakin heterogen. Kepala sekolah dituntut untuk membuat terobosan pelayanan pendidikan kepada peserta didik yang nampak beragam. Jangan ada kebijakan sekolah yang semakin membuat kondisi anak yang memiliki kemampuan intelektual di bawah ratarata menjadi minder. Sebaiknya kebijakan kelas unggulan tidak dilakukan. Kelas unggulan cenderung semakin menampakkan adanya diskrimisi. Keragaman peserta didik perlu dipertahankan dalam pengelompokan kelas secara umum. ${ }^{30}$

Keragaman kelas terwujud dari meleburnya anak yang memiliki kemampuan intelektualitas tinggi, sedang, dan rendah. Diharapkan keragaman ini menginisiasi mereka yang memiliki kemampuan intelektualitas sedang, bahkan rendah untuk mencontoh dan memotivasi mereka untuk memiliki semangat belajar yang kuat. Diharapkan keragaman ini akan membiasakan peserta didik menyikapi dan menyadari bahwa memang kehidupan masyarakat tidak mungkin homogen, tapi pasti beragam.

Dan tentunya ini juga menjadi tantangan sekaligus uji nyali kepada semua guru untuk menciptakan dan mendesain pembelajaran yang memberikan akses yang merata kepada semua peserta didik yang beragam. Guru dituntut agar keragaman anak memotivasi dirinya untuk semakin profesional dalam melaksanakan tugas pembelajaran sebagai wujud pelayanan prima kepada mereka. Pembelajaran yang dilakukan guru harus memberikan akses yang sama dan memberikan jaminan ramah lingkungan kepada mereka yang beragam. Mereka merasa betah berlama-lama mengikuti pembelajaran yang dilakukan oleh guru. Semua anak merasa tidak dalam kondisi dipaksa, tertekan, apalagi merasa diintimidasi. Pembelajaran memotivasi dan mengembangkan semua potensi yang dimiliki oleh semua anak.

Menurut Akh. Muzakki (Ketua Dewan Pendidikan Jatim dan Guru Besar UINSA Surabaya), "pembelajaran tidak perlu dipisah. Tidak perlu mengelompokkan peserta didik dengan mempertimbangkan kemampuan intelektual yang homogen. Penentuan kelas melebur kemampuan intelektual peserta didik yang beragam. Keragaman peserta didik perlu dipertahankan. Harapannya, sosialisasi peserta didik di sekolah bisa terbangun. Peserta didik juga terbiasa hidup dengan kondisi yang beragam. Kebiasaan peserta didik hidup dalam suasana keberagaman, melahirkan sikap dan perilaku toleran dan saling menghargai. Meski begitu, sekolah memang penting menyediakan pembelajaran tambahan. Terutama kepada peserta didik yang dirasa memiliki kemampuan intelektual kurang. Proses pembelajaran tidak disendirikan, sebab pembelajaran tidak sekedar akademik, tapi juga sosialisasi diri. Hal ini menuntut kepada guru untuk benar-benar profesional dalam mengelola proses pembelajaran sebagai upaya memberikan pelayanan prima kepada semua peserta didiknya". ${ }^{31}$

Guru harus memiliki kompetensi dan keterampilan dalam melakukan pengelolaan pembelajaran, mengelola pembelajaran pada dasarnya melakukan proses pendidikan, ini berarti bahwa "proses pendidikan yang terencana diarahkan untuk mewujudkan suasana belajar dan proses pembelajaran yang kondusif. Pendidikan tidak boleh mengesampingkan proses belajar. Pendidikan tidak semata-mata berusaha untuk mencapai hasil belajar, akan tetapi bagaimana memperoleh hasil

\footnotetext{
29 M. Alfan Alfian, "Politik Zonasi dalam Praktek Pendidikan di Indonesia", Jurna Politicon, Vol. 1 No. 2, (Desember 2019), 131

30 Khairunnisa Adinda, Suyoto, "Dampak Kebijakan Zonasi pada Penerimaan Peserta Didik Baru di SMAN 3 Yogyakarta dan SMAN 7 Yogyakarta", Jurnal Pendidikan Kewarganegaraan dan Hukum, Vol. 8 No. 8, (Tahun 2019), 818

31 Akh. Muzakki, MPLS Ramah Hingga Pemerataan Pembelajaran, (Jawa Pos, Senin, 15 Juli 2019), 8
} 
atau proses belajar yang terjadi pada peserta didik. Dengan demikian dalam pendidikan antara proses dan hasil belajar harus berjalan secara seimbang. Pendidikan yang hanya mementingkan salah satu diantaranya tidak akan dapat membentuk peserta didik yang berkembang secara utuh". ${ }^{32}$

"Dengan demikian, seluruh sekolah seharusnya melaksanakan proses pembelajaran seperti yang dirumuskan dalam standar proses pendidikan ini. Melakukan proses pembelajaran di kelas berarti membelajarkan para peserta didik secara terkondisi, mereka belajar dengan mendengar, menyimak, melihat, meniru apa-apa yang diinformasikan oleh guru atau fasilitator di depan kelas, dengan belajar seperti ini mereka memiliki perilaku sesuai dengan tujuan yang telah dirancangkan oleh guru. Tercapainya perilaku yang dikehendaki merupakan keberhasilan pembelajaran, akan tetapi banyak hal yang perlu diperhatikan dalam proses pembelajaran, tidak semua peserta didik akan mencapai perilaku sesuai yang diharapkan". ${ }^{33}$

Menjadi keharusan agar "penciptaan lingkungan belajar yang kondusif dan akademik, baik secara fisik maupun nonfisik perlu diwujudkan. Lingkungan fisik merupakan kodisi belajar yang harus didukung oleh berbagai sarana, laboratarium, dan media lain, serta lingkungan nonfisik memiliki peran yang besar juga dalam mempengaruhi kondisi belajar, terutama pengaturan lingkungan belajar, penampilan, sikap guru, hubungan harmonis antara guru dan peserta didik, peserta didik dengan guru, dan sesama peserta didik itu sendiri, serta organisasi dan bahan pembelajaran secara tepat, sesuai dengan kemampuan dan perkembangan peserta didik". ${ }^{34}$

Lingkungan belajar yang kondusif perlu diciptakan oleh guru yang profesional. Tuntutan ini akan dapat menciptakan "proses pembelajaran yang kondusif, semakin menyenangkan tatanan lingkungan fisik yang diciptakan oleh guru profesional, akan memberi dampak positif bagi proses pembelajaran. Para pakar psikolgis aliran ekologis telah mendapatkan temuan-temuan penelitian bahwa tata warna secara langsung mempengaruhi suasana jiwa yang optimistik, sedangkan penggunaan warna-warna suram akan memberikan pengaruh sebaliknya. Lingkungan belajar yang kondusif akan membuat peserta didik merasa betah dan senang mengikuti pembelajaran, tanpa merasa ditekan, terpaksa, apalagi diintimidasi". ${ }^{35}$

"Lingkungan belajar harus mendapatkan perhatian yang besar, karena lingkungan belajar mempengaruhi situasi pembelajaran. Peserta didik tidak akan merasa nyaman, aman, dan tentram belajar manakala kondisi lingkungan yang tidak mendukung suasana belajar. Oleh sebab itu hindarilah membangun sekolah di dekat adanya suara bising dari bunyi mesin yang ribut, pasar, dan jalan raya yang sibuk. Kemudian memperhatikan kebersihan sekolah dan sekitarnya, serta memperhatikan kenyamanan ruangan dengan menanamkan pohon-pohon di sekitar sekolah, menata ruang belajar yang menarik dan meyenangkan. Tempat duduk peserta didik dapat diubah sesuai dengan tujuan dan metode pembelajaran yang digunakan". ${ }^{36}$

"Lingkungan belajar yang kondusif menurut Mulyasa dapat dikembangkan melalui berbagai layanan sebagai berikut: (1) memberikan pilihan bagi peserta didik yang lambat maupun yang cepat dalam melakukan tugas pembelajaran, (2) memberikan pembelajaran remidial bagi peserta didik yang kurang berprestasi, atau berprestasi rendah, (3) mengembangkan organisasi kelas yang efektif,

\footnotetext{
32 Ayu Dwi Kusuma, Nani Imaniyati, "Pengembangan Profesi Guru Dalam Meningkatkan Kinerja Guru, Jurnal Medtek, Vol. 3 No. 2, (Oktober, 2011), 204

33 Tim Pengembang MKDP Kurikulum dan Pembelajaran, Kurikulum dan Pembelajaran, (Jakarta: PT RajaGrafindo, 2011), 128

34 Ali Mudhlofir, Pendidik Profesional: Konsep, Strategi, dan Aplikasinya dalam Peningkatan Mutu Pendidikan Di Indonesia, (Jakarta: Rajagrafindo Persada, 2013), 112

35 Syafrudin Nurdin, Profesi Keguruan, (Depok: Rajagrafindo Persada, 2019), 91

${ }^{36}$ Wina Sanjaya, Pembelajaran dalam Implementasi Kurikulum Berbasis Kompetensi, (Jakarta: Prenada Media Group, 2006 ), 157
} 
menarik, nyaman, dan aman bagi perkembangan potensi seluruh peserta didik secara optimal. Termasuk dalam hal ini, adalah penyediaan bahan pembelajaran menarik dan menantang bagi peserta didik, serta pengelolaan kelas yang tepat, efektif, dan efesien, (4) menciptakan kerjasama saling menghargai, baik antar peserta didik maupun antara peserta didik dengan guru dan pengelola pembelajaran lainnya. (5) melibatkan peserta didik dalam proses perencanaan belajar dan pembelajaran. Dalam hal ini, guru harus mampu memposisikan diri sebagai pembimbing dan manusia sumber, (6) mengembangkan proses pembelajaran sebagai tanggung jawab bersama antara peserta didik dan guru, sehingga guru lebih banyak bertindak sebagai fasilitator, dan sebagai sumber belajar, (7) mengembangkan sistem evaluasi belajar dan pembelajaran yang menekankan pada evaluasi diri sendiri (self evaluation)". ${ }^{37}$

"Pelayanan di atas diharapkan mampu menciptakan iklim belajar yang kondusif, menarik, nyaman, aman, tenang, dan menyenangkan (Joyfull teaching and learning), sehingga aktivitas pembelajaran yang dilakukan akan menimbulkan gairah, semangat, dan hasrat belajar peserta didik. Iklim belajar yang kondusif membangkitkan minat belajar peserta didik. Minat belajar peserta didik penting mendapat perhatian dari guru, ketika minat belajar mereka menjadi kuat, maka berimplikasi pada keikutsertaan mereka secara aktif dalam proses pembelajaran". ${ }^{38}$

\section{Optimalisasi Pemerataan Pendidikan Berbasis Zonasi}

Optimalisasi pemerataan pendidikan berbasis zonasi di Pamekasan belum sepenuhnya optimal, seperti yang dikatakan oleh beberapa informan, zonasi yang menjadi kebijakan baru dari pemerintah, masih belum optimal untuk memeratakan pendidikan, karena ternyata beberapa sekolah yang biasanya kebanjiran calon peserta didik baru, setelah pola zonasi diberlakukan, mengalami kekurangan pendaftar, bahkan hampir semua sekolah kekurangan pendaftar, termasuk sekolah yang dipandang favorit oleh masyarakat, walaupun memang di sekolah favorit tidak terlalu banyak kurangnya. ${ }^{39}$

Kemudian beberapa informan yang lain menyatakan, zonasi yang dijadikan pijakan dalam penerimaan peserta didik baru oleh pemerintah, belum sepenuhnya memeratakan akses pendidikan pada semua sekolah. Indikasi yang nampak adalah sekolah yang dipandang favorit oleh masyarakat, ternyata setelah diberlakukan kebijakan zonasi ini, kekurangan pendaftar. Sekolah favorit sudah mengakar di hati masyarakat. Dan tidak dipungkiri bahwa memang masyarakat tetap memiliki kepercayaan yang kuat pada sekolah yang dipandang favorit. Ketika masyarakat ada pada zona sekolah yang dipandang tidak favorit, pasti masyarakat menyikapi dengan sikap kecewa. ${ }^{40}$

Pengamatan yang dilakukan oleh peneliti, sikap dan perilaku masyarakat masih tetap menginginkan anaknya melanjutkan pada lembaga pendidikan yang favorit. Masyarakat masih berupaya mencari kesempatan untuk dapat memasukkan anaknya pada sekolah yang dipandang favorit, oleh karena itu, kepada semua sekolah harus transparan dan konsisten melaksanakan zonasi ini dengan sebaik-baiknya, jangan sampai ada sekolah yang memberikan peluang kepada masyarakat di luar zona, karena kouta belum terpenuhi, secara diam-diam sekolah memberikan kesempatan

\footnotetext{
${ }^{37}$ Mulyasa, Menjadi Guru Profesional, (Bandung: Remaja Rosdakarya, 2005), 16-17

38 Ali Muhson, "Meningkatkan Profesionalisme Guru Sebuah Harapan”, Jurnal Ekonomi Dan Pendidikan, Vol. 2 No. 1 (Agustus, 2004), 93

39 Hafiluddin anggota masyarakat dari Kangenan kecamatan Pamekasan, Aisyah anggota masyarakat dari Jalmak kecamatan Pamekasan, Hasanuddin anggota masyarakat dari Bettet kecamatan Pamekasan, wawancara, (20, 22, dan 27 April 2019)

40 Abd. Aziz kepala SMAN 3 Pamekasan, Kamaruddin kepala SMAN 2 Pamekasan, Jamil kepala SMPN 8 Pamekasan, wawancara, (8, 9, dan 10 April 2019)
} 
kepada masyarakat di luar zona. Kalau itu terjadi, maka semakin menjerit dan sangat kecewa masyarakat terhadap pemberlakuan zonasi ini. ${ }^{41}$

Dari pengamatan peneliti, ada sikap dan perilaku menarik yang ditampilkan oleh masyarakat untuk mencarikan sekolah yang terbaik bagi anak-anaknya. Masyarakat yang tingkat ekonominya menengah ke bawah, harus mengikuti dan mendaftarkan anaknya ke sekolah sesuai zona, walaupun sebenarnya berat bagi mereka, karena pada dasarnya mereka tetap tidak menerima, cuma tidak ada pilihan lain, atau memilih madrasah negeri yang ada di lingkungan kota Pamekasan yang belum memberlakukan zonasi dan masih ada kelas unggulan yang seleksinya beda dengan kelas reguler (dua tahun terakhir setelah pemberlakuan zonasi ada peningkatan yang luar biasa calon peserta didik baru yang mendaftar) atau sekolah swasta seperti SMP Plus Nurul Hikmah Pamekasan (dua tahun terakhir semenjak zonasi diberlakukan mengalami peningkatan signifikan jumlah pendaftar calon peserta didik baru). Tetapi bagi masyarakat yang status ekonominya menengah ke atas, pasti berupaya dengan mencari alternatif ke lembaga pendidikan yang dipandang unggul dan berkualitas yang ada di luar madura. ${ }^{42}$

Pola zoansi belum optimal memeratakan akses pendidikan pada semua sekolah. Pada kenyataan masyarakat tetap ingin pada sekolah yang unggul dan berkualitas. Sebenarnya bagi pemerintah harus berupaya pada semua sekolah harus diyakini berkualitas oleh masyarakat. Tentunya untuk mengupayakan agar dipandang berkualitas oleh masyarakat, menjadi penting bagi pemerintah untuk mengupayakan agar semua sekolah yang dimiliki oleh pemerintah dikelola dengan profesional. $^{43}$

Dari tabel 1 nampak jelas, satu-satunya sekolah antara pagu dan pendaftar sama adalah hanya SMAN 2 Pamekasan. Padahal sebelum kebijakan zonasi ini diberlakukan, untuk jenjang SMAN yang dipandang favorit oleh masyarakat adalah SMAN 1 dan SMAN 3, sementara untuk jenjang SMPN yang dipandang favorit oleh masyarakat adalah SMPN 1 dan SMPN 2. Sekolah yang dipandang favorit oleh masyarakat, ketika kebijakan zonasi belum diberlakukan, sekolah itu kebanjiran pendaftar, sehingga pendaftar berkompetisi ketat dan sehat. Tetapi sebaliknya, ketika kebijakan zonasi ini diberlakukan kekurangan pendaftar, dan bahkan hampir semua sekolah kekurangan pendaftar, kecuali SMAN 2. Ini mengindikasikan kebijakan zonasi belum optimal memeratakan pendidikan pada semua sekolah.

\footnotetext{
${ }^{41}$ Observasi terhadap sikap dan perilaku masyarakat, (18 dan 27 April 2019)

42 Observasi terhadap sikap dan perilaku masyarakat, (8, 9, dan 10 April 2019)

${ }^{43}$ Eva Yusnita guru SMAN 2 Pamekasan, Hidayat Santoso guru SMPN 8 Pamekasan, Jundiyatul Karimah guru SMPN 6 Pamekasan, wawancara, (9, 10, dan 11 April 2019)
} 
Tabel 1

PPDB SMAN Dan SMPN Di Kecamatan Kota Pamekasan

Tahun Pelajaran 2019/2020

\begin{tabular}{ccccc}
\hline No & Sekolah & Pagu & Terisi & Kekurangan \\
\hline 1 & SMAN 1 Pamekasan & 304 & 277 & 27 \\
2 & SMAN 2 Pamekasan & 319 & 319 & 0 \\
3 & SMAN 3 Pamekasan & 287 & 214 & 73 \\
4 & SMAN 4 Pamekasan & 278 & 110 & 168 \\
5 & SMAN 5 Pamekasan & 189 & 64 & 125 \\
6 & SMPN 1 Pamekasan & 288 & 202 & 86 \\
7 & SMPN 2 Pamekasan & 259 & 230 & 29 \\
8 & SMPN 3 Pamekasan & 172 & 121 & 51 \\
9 & SMPN 4 Pamekasan & 263 & 113 & 150 \\
10 & SMPN 5 Pamekasan & 258 & 119 & 139 \\
11 & SMPN 6 Pamekasan & 173 & 72 & 101 \\
12 & SMPN 7 Pamekasan & 201 & 91 & 110 \\
13 & SMPN 8 Pamekasan & 202 & 129 & 73 \\
\hline
\end{tabular}

Zonasi yang menjadi kebijakan pemerintah secara nasional belum optimal memeratakan kesempatan mengakses pendidikan pada semua sekolah. Sebenarnya yang paling penting untuk mendapat perhatian semua pihak adalah bagaimana kualitas pendidikan ini merata di semua sekolah, ketika kualitas pendidikan sudah merata pada semua sekolah, tanpa ada kebijakan zonasi, pasti masyarakat akan mencari sekolah yang dekat dan berkualitas. Pola zonasi yang diberlakukan oleh pemerintah belum sepenuhnya meratakan pendidikan pada semua sekolah. Memeratakan anak yang berprestasi pada semua sekolah, ya, tapi memeratakan mendapatkan pelayanan pendidikan yang berkualitas belum nampak, karena kualitas sekolah belum merata.

"Pemerataan pendidikan merupakan implementasi dari pendidikan demokratis yang mencerminkan adanya pemerataan pendidikan. Pemerataan pendidikan mencakup dua aspek penting yaitu; equality dan equity. Equality atau persamaan mengandung arti persamaan kesempatan untuk memperoleh pendidikan, sedangkan equity bermakna keadilan dalam memperoleh kesempatan pendidikan yang sama diantara berbagai kelompok dalam masyarakat. ${ }^{44}$ Akses terhadap pendidikan yang merata berarti semua penduduk usia sekolah telah memperoleh kesempatan pendidikan, sementara itu akses terhadap pendidikan telah adil jika antarkelompok bisa menikmati pendidikan secara sama". ${ }^{45}$

Pemerataan pendidikan harus dapat diakses sama oleh semua masyarakat, ketika masyarakat membutuhkan pelayanan jasa pendidikan dari sekolah. Tidak bisa akses pendidikan, hanya dimiliki oleh pihak-pihak tertentu, kesempatan memperoleh pendidikan diatur dengan zona, sementara di luar zona, menjadi hilang kesempatan untuk memperoleh akses pelayanan pendidikan. Bila ada pihak-pihak tertentu tidak leluasa mendapatkan akses pendidikan secara merata, maka ini berarti pemerataan pendidikan belum diperoleh betul oleh masyarakat. Pendidikan hanya memberi

44 Mujahidun, "Pemerataan Pendidikan Anak Bangsa: Pendidikan Gratis Versus Kapitalisme Pendidikan", Jurnal Tarbiyatuna, Vol. 7 No. 1, (Juni 2016), 43

${ }^{45}$ Muhammad Idrus, "Mutu Pendidikan dan Pemerataan Pendidikan di Daerah", Jumal Psikopedagogia, Vol. 1 No. 2, (Desember 2012) 
pelayanan pada segelintir masyarakat, tidak pada semua masyarakat. Kunci pendidikan itu Cuma dua; akses dan kualitas. Bisa diakses tapi tidak berkualitas. Berkualitas, tapi sulit diakses. ${ }^{46}$ Pola zonasi yang merupakan kebijakan baru dari pemerintah, baru dua tahun kebijakan zonasi ini diberlakukan, dimaksudkan untuk membuka akses dengan kualitas yang merata pada semua lembaga pendidikan, sehingga pada akhirnya akan menghilangkan adanya sekolah favorit dan tidak favorit. Memang ini masih perlu dievaluasi terus demi untuk semakin menyempurkan. Di samping juga harus diimbangi dengan kebijakan lain, seperti; penyebaran guru yang kompeten pada semua sekolah, kompetensi manajerial kepala sekolah yang mumpuni, pemerataan sarana dan prasarana, dan penciptaan iklim belajar yang kondusif.

Pola zonasi dimaksudkan sebagai upaya pemerintah untuk memeratakan akses pelayanan pendidikan dan peningkatan mutu pendidikan. Karena memang dirasakan, dewasa ini betapa banyak sekolah yang rendah mutu bahkan tidak bermutu. Hal ini sering kali disebabkan oleh manajemen sekolah yang carut marut dan kondisi guru yang tidak berkualitas dalam melaksanakan pembelajaran. Kondisi ini tidak boleh dibiarkan berkelanjutan. Oleh sebab itu, dibutuhkan kehadiran kepala sekolah yang memiliki standar kualifikasi akademik memadai dan standar kompetensi yang sangat baik, berdedikasi, beretos kerja tinggi, disiplin, berpengalaman, kreatif, proaktif, profesional, bertanggung jawab akan tugas dan fungsinya, mencintai profesi, dan berkomitmen tinggi akan mampu memainkan perannya memecahkan persoalan kualitas pendidikan di sekolah dan memperbaiki manajemen sekolah, serta guru melakukan proses pembelajaran yang bermutu, sehingga secara bertahap sekolah ke depan menjadi terangkat mutunya. Hanya lembaga pendidikan yang berkualitas yang menjadi harapan semua orang. "Kualitas lembaga pendidikan akan mewujudkan profil lulusan yang dicita-citakan bersama, yaitu lulusan yang memiliki iman dan taqwa kepada Tuhan yang maha Esa, berkhlaq mulia, sehat, berilmu, mandiri, kreatif, inovatif, demokratis, dan tanggung jawab". ${ }^{47}$

Pemerataan pendidikan berbasis zonasi belum sepenuhnya memeratakan kesempatan mengakses pendidikan bagi semua orang untuk memperoleh pelayanan pendidikan yang unggul dan bagus. Dalam hal memeratakan prestasi calon peserta didik tidak pada satu sekolah, tetapi pada semua sekolah, jawabannya, ya, cuma pemerataan yang perlu dan pasti harus dilakukan adalah pada pemerataan kualitas pendidikan. "Pemerataan kualitas pendidikan tidak bergantung kepada raw-input yang masuk ke sekolah. Tetapi yang paling strategis dan urgen adalah bagaimana pengelolaan pendidikan dilakukan oleh orang yang memiliki komitmen dan keahlian yang berkualitas" ${ }^{48}$ Sekolah penting diberi kebebasan dan kewenangan untuk berkreasi dan berinovasi dalam melakukan pengelolaan pendidikan di sekolah. Kreativitas dan inovasi sekolah tentunya berorientasi pada peningkatan proses pendidikan di sekolah. Dan tuntutan ini sebenarnya sudah dibuka oleh pemerintah sebagai implikasi dari tuntutan reformasi pendidikan. "Indikasi ini menjadi kuat dengan dilakukan perubahan undang-undang nomor 2 tahun 1989 menjadi undang-undang nomor 20 tahun 2003 tentang sistem pendidikan nasional. Sebab kebebasan mengelola sudah dimiliki oleh sekolah, maka pemerintah pusat perlu menentukan standar pendidikan sebagai standar minimal yang harus

\footnotetext{
${ }^{46}$ Retno Listyarti, Komisioner KPAI bidang pendidikan, Kunci Pendidikan: Akses dan Kualitas, (Jawa Pos, Kamis 20 Juni 2019), 1

47 Marus Suti, “Strategi Peningkatan Mutu Di Era Otonomi Pendidikan”, Jurnal Medtek, Vol. 3 No. 2, (Oktober, 2011), 199

${ }^{48}$ Lukman Hakim, "Pemerataan Akses Pendidikan bagi Rakyat sesuai dengan Amanat Undang-Undang Nomor 20 Tahun 2003 Tentang Sistem Pendidikan Nasional”, Jurnal Edutech, Vol. 2 No. 1, (Maret 2016), 56
} 
dijadikan pedoman oleh semua sekolah. Menurut Tilaar standar pendidikan mencakup; 1) standar kurikulum, 2) standar performance, dan 3) kesempatan belajar". ${ }^{49}$

"Standar pemerataan pendidikan merupakan standar minimal yang harus dipenuhi oleh setiap satuan pendidikan. Standar pemerataan pendidikan mengacu pada standar nasional pendidikan. Standar nasional pendidikan adalah suatu kriteria atau standar minimal terkait pelaksanaan sistem pendidikan yang ada di seluruh wilayah hukum Negara Kesatuan Republik Indonesia. Fungsi dari standar nasional pendidikan adalah sebagai dasar melakukan perencanaan, pelaksanaan, dan pengawasan pendidikan untuk mewujudkan pendidikan nasional yang berkualitas. Sedangkan tujuan utama standar nasional pendidikan adalah menjamin mutu pendidikan nasional guna mencerdaskan kehidupan bangsa, membentuk karakter, dan peradaban bangsa yang bermartabat. Standar nasional pendidikan diselenggarakan secara terencana, terarah, dan berkesinambungan sesuai kebutuhan dan perubahan kehidupan nasional dan global. Standar nasional pendidikan mencakup delapan kriteria yang wajib terpenuhi bagi semua satuan pendidikan dalam upaya menuju pendidikan yang berkualitas. Standar nasional pendidikan mencakup; standar isi, standar proses, standar kompetensi lulusan, standar tenaga pendidik dan kependidikan, standar sarana dan prasarana, standar pengelolaan, standar pembiayaan, dan standar penilaian." 50

Selanjutnya dalam "Peraturan Pemerintah Nomor 13 Tahun 2015 Tentang Standar Nasional Pendidikan, pada pasal 1 ayat 5 sampai dengan ayat 12, ditegaskan, standar kompetensi lulusan merupakan kriteria atau kualifikasi yang menyangkut kemampuan lulusan yang terbagi atas kemampuan sikap, pengetahuan, dan keterampilan. Standar isi mencakup materi minimal dan tingkat kompetensi minimal untuk mencapai kompetensi lulusan minimal untuk jenis dan jenjang pendidikan tertentu. Di dalam standar isi terdapat kerangka dasar dan struktur kurikulum, beban belajar, kurikulum tingkat satuan pendidikan, dan kalender pendidikan. Standar isi mencakup penentuan dan pelaksanaaan kurikulum. Standar proses pendidikan berkaitan dengan pelaksanaan pembelajaran, yang berarti dalam standar proses pendidikan berisi bagaimana seharusnya proses pembelajaran berlangsung. Standar proses pendidikan dimaksud dapat dijadikan pedoman bagi guru dalam pengelolaan pembelajaran. Standar tenaga pendidik dan tenaga kependidikan berorientasi kepada tenaga pendidik yang harus mempunyai kualifikasi akademik dan kompetensi sebagai agen pembelajaran, sehat rohani dan jasmani, serta mampu mewujudkan tujuan pendidikan nasional. Standar sarana dan prasarana mengharuskan semua satuan pendidikan harus dilengkapi dengan sarana pendidikan seperti media pendidikan, peralatan pendidikan, buku dan sumber belajar lainnya, perabot, dan perlengkapan lainnya. Standar pengelolaan mengharuskan kepada semua satuan pendidikan dikelola secara profesional. Satuan pendidikan sebagai suatu institusi/lembaga pendidikan harus ada top leader yang cerdas, cermat, inovasi, dan kreatif guna melakukan pengelolaan profesional. Standar pembiayaan mencakup perencanaan, pelaksanaan, dan pengawasan kegiatan pendidikan secara efektif dan efesien. Standar penilaian ini berkaitan dengan segala macam mekanisme, prosedur, instrumen penilaian untuk mengetahui hasil belajar peserta didik."

Delapan standar nasional pendidikan ini merupakan barometer untuk mengukur kualitas pendidikan secara nasional. Pemerataan pendidikan seyogianya menyiapkan dan mengharuskan lembaga pendidikan untuk memenuhi pada tuntutan dan standar yang telah ditetapkan dalam standar nasional pendidikan. Ketika semua sekolah sudah memenuhi pada delapan standar dimaksud, maka pasti akan terjadi pemerataan pendidikan. Menurut Tilaar "fungsi standar nasional pendidikan adalah pertama untuk pengukuran kualitas pendidikan. Standar pengukuran tidak statis, tetapi semakin lama semakin ditingkatkan. Ada standar ideal dan standar operasional temporal. Standar ideal dapat

${ }^{49}$ Tilaar, Standarisasi Pendidikan Nasional Suatu Tinjauan Kritis, (Jakarta: Rineka Cipta, 2006), 79

50 Tilaar, Manajemen Pendidikan Nasional, 76-77 
ditentukan setiap 5 atau 10 tahun, sedangkan standar operasional temporal dapat ditentukan setiap tahun. Standar ideal juga bertahap untuk dicapai seperti standar isi yaitu kurikulum sekolah perlu direvisi setiap sekurang-kurangnya 5-10 tahun. Kedua, pemetaan masalah pendidikan. Dan ketiga penyusunan strategi dan pengembangan sesudah diperoleh data dari evaluasi belajar secara nasional seperti ujian akhir nasional". ${ }^{51}$

\section{Penutup}

Hasil penelitian ini dapat disimpulkan: pertama, respon masyarakat ada dua, sebagian besar tidak setuju dan ada beberapa yang setuju. Respon masyarakat yang tidak setuju beralasan diantaranya; mengekang kebebasan, mengabaikan kompetisi akademik, tidak menjunjung tinggi prinsip keadilan, melahirkan diskriminasi baru. Kemudian respon masyarakat yang setuju memiliki beberapa alasan, antara lain; memberi kesempatan yang sama kepada semua masyarakat untuk mendapatkan pelayanan pendidikan yang merata, memeratakan calon peserta didik yang berprestasi kepada semua sekolah, sebagai suatu upaya untuk menghilangkan predikat sekolah favorit dan tidak favorit.

Kedua, respon sekolah ada dua. Ada beberapa memberikan respon setuju dengan beberapa alasan, antara lain; memberi akses yang sama untuk mendapatkan pelayanan pendidikan yang merata, memeratakan keunggulan dan kualitas pada semua sekolah, sebagai upaya untuk menghilangkan image masyarakat terhadap sekolah unggul dan tidak unggul. Kemudian pada umumnya memberikan respon tidak setuju, sebab; mengeleminasi dan membatasi sekolah mendapatkan calon peserta didik baru yang berkualitas, mengabaikan prestasi akademik, tidak menjunjung tinggi semangat reformasi.

Ketiga, pemerataan pendidikan berbasis zonasi masih belum optimal, hal ini diindikasikan karena; belum sepenuhnya memeratakan akses pendidikan pada semua sekolah, terbukti hampir semua sekolah kekurangan jumlah pendaftar, kecuali pada sekolah yang dipandang favorit oleh masyarakat, walaupun hanya sekedar memenuhi sesuai dengan pagu yang ditentukan, image masyarakat pada sekolah favorit dan tidak favorit sulit dihilangkan, pemerataan pendidikan dengan pola zonasi, harus di-follow up-i dengan kebijakan lain seperti; penyebaran guru berkualitas pada semua sekolah, peningkatan kompetensi manajerial kepala sekolah, dan penguatan kembali standar nasional pendidikan untuk diimplementasikan dengan sunguh-sungguh oleh semua satuan pendidikan sebagai institusi penyelenggara pendidikan, sehingga semua sekolah menjadi unggul dan berkualitas, pasti masyarakat akan menyekolahkan anaknya pada sekolah yang unggul dan berkualitas serta dekat dengan rumah. Wallahu a'lam.

\section{DAFTAR PUSTAKA}

Adinda, Khairunnisa, Suyoto, "Dampak Kebijakan Zonasi Pada Penerimaan Peserta Didik Baru di SMAN 3 Yogyakarta dan SMAN 7 Yogyakarta", Jurnal Pendidikan Kewarganegaraan dan Hukum, Vol. 8 No. 8, 2019

Alfian, Alfan, M., "Politik Zonasi Dalam Praktek Pendidikan Di Indonesia", Jurnal Politicon, Vol. 1 No. 2, Desember 2019

Dewi, Anggia, Tiara, "Pengaruh Profesionalisme Guru Dan Motivasi Kerja terhadap Kinerja Guru Ekonomi SMA Se Kota Malang”, Jurnal Pendidikan Ekonomi, Vol. 3 No. 1, 2005

Ekosiswoyo, Rasdi, "Kepemimpinan Kepala Sekolah Yang Efektif Kunci Pencapaian Kualitas Pendidikan”, Jurnal Ilmu Pendidikan, Jilid 14 No. 2, Juni, 2007

Fattah, Nanang, Analisis Kebijakan Pendidikan, Bandung: Remaja Rosdakarya, 2014

${ }^{51}$ Tilaar, Standarisasi Pendidikan, 108-109 
Saiful Arif

Hakim Lukman, "Pemerataan Akses Pendidikan Bagi Rakyat Sesuai Dengan Amanat UndangUndang Nomor 20 Tahun 2003 Tentang Sistem Pendidikan Nasional", Jurnal Edutech, Vol. 2 No. 1, Maret 2016

Idrus, Muhammad, "Mutu Pendidikan dan Pemerataan Pendidikan Di Daerah", Jurnal Psikopedagogia, Vol. 1 No. 2, Desember 2012

Aniek Indrawati, "Pengaruh Kualitas Layanan Lembaga Pendidikan terhadap Kepuasan Konsumen", Jumal Ekonomi Bisnis,Th. 16 No. 1, Maret, 2011

Kemendikbud, Penerimaan Peserta Didik Baru Pada Taman Kanak-Kanak, Sekolah Dasar, Sekolah Menengah Pertama, Sekolah Menengah Atas, dan Sekolah Menengah Keburuan, Jakarta: Permendikbud No. 51 Tahun 2018

Kusuma, Dwi, Ayu, Imaniyai, Nani, "Pengembangan Profesi Guru Dalam Meningkatkan Kinerja Guru, Jurnal Medtek, Vol. 3 No. 2, Oktober, 2011

Listyarti, Retno, Komisioner KPAI bidang pendidikan, Kunci Pendidikan: Akses Dan Kualitas, Jawa Pos, Kamis 20 Juni 2019

Mudhlofir, Ali, Pendidik Profesional: Konsep, Strategi, Dan Aplikasinya Dalam Peningkatan Mutu Pendidikan Di Indonesia, Jakarta: Rajagrafindo Persada, 2013

Mulyasa, E, Manajemen Berbasis Sekolah (Konsep, Strategi, dan Implementasi), Bandung: Remaja Rosdakarya, 2003

Mulyasa, E, Menjadi Guru Profesional, Bandung: Remaja Rosdakarya, 2005

Mujahidun, "Pemerataan Pendidikan Anak Bangsa: Pendidikan Gratis Versus Kapitalisme Pendidikan", Jurnal Tarbiyatuna, Vol. 7 No. 1, Juni 2016

Muhson, Ali, "Meningkatkan Profesionalisme Guru Sebuah Harapan", Jurnal Ekonomi Dan Pendidikan, Vol. 2 No. 1 Agustus, 2004

Muzakki, Akh., MPLS Ramah Hingga Pemerataan Pembelajaran, Jawa Pos, Senin, 15 Juli 2019

Nurdin, Syafrudin, Profesi Keguruan, Depok: Rajagrafindo Persada, 2019

Nurlailiyah, Aris, "Analisis Kebijakan Sistem Zonasi terhadap Perilaku Siswa Di Yogyakarta”, Jurnal Realita Vol. 17 No. 1, Januari 2019

Peraturan Pemerintah Nomor 13 Tahun 2015 Tentang Standar Nasional Pendidikan

Tilaar, H.A.R., Manajemen Pendidikan Nasional, Bandung: Remaja Rosdakarya, 2004

Tilaar, H.A.R., Standarisasi Pendidikan Nasional Suatu Tinjanan Praktis, Jakarta: Rineka Cipta, 2006

Tim Pengembang MKDK Kurikulum dan Pembelajaran, Kurikulum dan Pembelajaran, Jakarta: Rajagrafindo Persada, 2011

Undang-Undang Dasar Republik Indonesia Tahun1945

Raharjo, Budi, Sabar, "Evaluasi Trend Kualitas Pendidikan Di Indonesia", Jurnal Penelitian Dan Evaluasi Pendidikan, Tahun 16 Nomor 2, 2012

Undang-Undang Nomor 20 Tahun 2003 Tentang Sistem Pendidikan Nasional

Sanjaya, Wina, Pembelajaran Dalam Implementasi Kurikulum Berbasis Kompetensi, Jakarta: Prenada Media Group, 2006

Safarah, Arifinna, Azizah, "Program Zonasi di Sekolah Dasar Sebagai Upaya Pemerataan Kualitas Pendidikan di Indonesia", Jurnal Lentera Pendidikan, Vol. 21 No. 2, Desember 2018

Sukemi, PPDB: Upaya Pemerataan Pendidikan, Jawa Pos, Kamis, 20 Juni 2019

Sujanto, Bedjo, Pengelolaan Sekolah Permasalahan dan Solusi, Jakarta: Bumi Aksara, 2018

Suti, Marus, "Strategi Peningkatan Mutu Di Era Otonomi Pendidikan", Jurnal Medtek, Vol. 3 No. 2, Oktober, 2011 